DOI 10.14746/ssp.2015.1.7

Jędrzej SKRZYPCZAK

Uniwersytet im. Adama Mickiewicza w Poznaniu

\title{
Elektroniczne systemy antyplagiatowe jako narzędzie wykrywania przypadków plagiatu w pracach studentów i pracowników naukowych ${ }^{1}$
}

Streszczenie: Masowość kształcenia akademickiego, a zwłaszcza możliwość łatwego dostępu do ogromnego bogactwa źródeł i opracowań dostępnych w internecie, spowodowały, że przypadki naruszenia praw autorskich są nagminne. Począwszy od 1 października 2014 r. szkoły wyższe w Polsce zostały zobowiązane do sprawdzania pisemnych prac dyplomowych przed egzaminem dyplomowym z wykorzystaniem programów antyplagiatowych współpracujących z ogólnopolskim repozytorium pisemnych prac dyplomowych. Artykuł podejmuje próbę wyjaśnienia wątpliwości w jaki sposób te systemy informatyczne funkcjonują i jakie jest ich znaczenie, jeżeli chodzi o konsekwencje prawne wykrytych niedopuszczalnych zapożyczyć. Poruszono kwestię prawa cytatu w polskim prawie autorskim. Komputerowe programy antyplagiatowe są instrumentem przydatnym, ale nie idealnym. Z pewnością żaden z promotorów lub recenzentów pracy naukowej nie jest w stanie stwierdzić wszystkich zapożyczeń z cudzych utworów, co przy pomocy tych systemów jest możliwe. Wśród wad należy wymienić - mimo wszystko - ciagle wąską bazę materiałów porównawczych. Istnieją także łatwe sposoby oszukania systemu. Co jednak istotniejsze, systemy te nie uwzględniają do końca specyfiki i istoty ochrony praw autorskich. Rozwiązanie to może być użyteczne, bowiem pomagające wykryć nieetyczne praktyki. Jednak koniecznie wymaga zweryfikowania przez promotora.

Słowa kluczowe: elektroniczne systemy antyplagiatowe, plagiat, naruszenie praw autorskich, prawo cytatu

$\mathrm{M}$ asowość kształcenia akademickiego, ale zwłaszcza możliwość łatwego dostępu do ogromnego bogactwa źródeł i opracowań dostępnych w internecie, spowodowały, że przypadki naruszenia praw autorskich sa

Wynagrodzenie autorskie sfinansowane zostało przez Stowarzyszenie Zbiorowego Zarządzania Prawami Autorów Twórców Dzieł Naukowych i Technicznych KOPIPOL z siedzibą w Kielcach z opłat uzyskanych na podstawie art. 20 oraz art. $20^{1}$ ustawy o prawie autorskim i prawach pokrewnych. 
obecnie nagminne. Potwierdzają to m.in. wyniki kontroli przeprowadzonej przez Najwyższą Izbę Kontroli (Informacja, 2014, s. 7-14). W dokumencie odnotowano częste przypadki naruszania praw autorskich w pracach dyplomowych studentów szkół wyższych. Jak wyjaśniono, najczęściej takie praktyki polegały bądź na umieszczaniu zapożyczonych w sposób nieuprawniony od innych autorów fragmentów cudzych prac, bądź na zlecaniu przygotowania całej pracy innej osobie tzw. ghostwriterowi, a następnie oznaczeniu takiego dzieła własnym nazwiskiem. W konkluzjach raportu stwierdzono, że choć w większości z kontrolowanych szkół wyższych podjęto pewne działania mające wykluczyć takie niepożądane zachowania, to jednak stosowane rozwiązania - zdaniem NIK - wydawały się być niewystarczające, bowiem skuteczność wykrywania naruszeń w ocenie kontrolujących była niesatysfakcjonująca. Wśród instrumentów walki z takimi praktykami, najczęściej stosowanymi w większości badanych placówek były m.in. stosowne oświadczenia dyplomantów o samodzielności przygotowania pracy, jak również - co należy w sposób szczególny podkreślić w kontekście analizowanego tu problemu badawczego - wykorzystywanie informatycznych programów antyplagiatowych. Stwierdzono istnienie takich systemów w 12 na 14 zbadanych ośrodków naukowych. Ponadto kontrola wytknęła szkołom wyższym, iż w 10 przypadkach podjęte działania organizacyjne nie zapewniały np. rzetelnego sprawowania opieki promotora, z uwagi na zbyt duże obciążenie pracowników naukowych. Dodatkowo w raporcie pokontrolnym wyraźnie stwierdzono, że ,programy antyplagiatowe, choć ułatwiają wykrycie nieuprawnionych zapożyczeń, nie mogą zapewnić ochrony oryginalności prac. Ich skuteczność w znacznej mierze determinuje wykorzystywana do porównań baza danych. Kluczowe znaczenie ma także sposób interpretacji przez promotorów wyników badania pracy w programie. Wyniki kontroli wskazują na przypadki zarówno nieuzasadnionego ignorowania ich, jak i posługiwania się nimi w sposób bezkrytyczny, co w skrajnym przypadku doprowadziło do modyfikacji pracy dyplomowej już po jej obronie" (Informacja, 2014, s. 9).

Warto podkreślić, że od 1 października 2014 r. - zgodnie z art. 167a ust. 4 Prawa o szkolnictwie wyższym (ustawa 2014) - szkoły wyższe zostały zobowiązane do sprawdzania pisemnych prac dyplomowych przed egzaminem dyplomowym z wykorzystaniem programów antyplagiatowych współpracujących z ogólnopolskim repozytorium pisemnych prac dyplomowych. Dodatkowo rektorzy uczelni w terminie do 31 grudnia 2016 r. zostali zobowiązani wprowadzić do ogólnopolskiego repozytorium pisemnych prac dyplomowych dane dotyczące prac dyplomowych, 
których obrona zakończyła się pozytywnym wynikiem i odbyła się po dniu 30 września 2009 r. Repozytorium ma być elementem obecnie funkcjonującego Systemu Informacji o Szkolnictwie Wyższym, prowadzonego w systemie informatycznym POL-on (http://polon.nauka.gov.pl). Podmiotem odpowiedzialnym za prowadzenie ogólnopolskiego repozytorium prac dyplomowych jest Minister Nauki i Szkolnictwa Wyższego, natomiast wybór programu antyplagiatowego w każdej placówce naukowej będzie należał bezpośrednio do uczelni. Jak dotąd powyższe rozwiązania dotyczą wyłącznie prac studentów, należy jednak domniemywać, że w przyszłości obejmować one będą także utwory pracowników naukowych. W każdym razie nie ma w tym zakresie żadnych przeszkód, aby tak było już obecnie. Z przykrością należy stwierdzić, że niestety znane są przypadki naruszeń praw autorskich na poziomie doktoratów i habilitacji oraz innych typów prac naukowych.

Pojawiają się jednak wątpliwości w jaki sposób antyplagiatowe systemy informatyczne funkcjonują i jak należy oceniać wynik ich pracy w kontekście obowiązującego prawa autorskiego. Mechanizmy te zostaną przedstawione na podstawie działania serwisu Plagiat.pl ${ }^{2}$. Trzeba podkreślić, że przywołanie tej marki nie ma służyć w żadnej mierze promocji lub reklamie tego produktu, ani tym bardziej dyskredytowaniu tej usługi, ale jedynie wskazanie pewnego mechanizmu, który może powodować poważne konsekwencje prawne dla studentów, doktorantów i pracowników naukowych. Otóż zgodnie z założeniami twórców tego serwisu generowany przez ten system tzw. raport podobieństwa, czyli rezultat poddania ocenie danego tekstu pod kątem istnienia w nim zapożyczeń, ma ułatwić ocenę samodzielności badanego tekstu oraz wskazać liczbę fragmentów pochodzących z innych opracowań wraz z podaniem ich źródeł. Serwis ten wskazuje tzw. współczynniki podobieństwa, które określają „,w jakim procencie praca składa się z fragmentów identycznych z wykrytymi w innych tekstach oraz są stosunkiem liczby wyrazów odnalezionych w innych tekstach do całkowitej liczby wyrazów w badanym dokumencie" (Instrukcja, 2014). System generuje ich kilka. I tak współczynnik nr 1 podaje wszystkie odszukane frazy zawierające ciąg pięciu identycznych wyrazów. Współczynnik nr 2 wskazuje odszukane identyczne frazy o długości co najmniej 25 wyrazów. Natomiast współczynniki podobieństwa nr 3, 4 i 5 - jak podaje administrator

2 Na rynku dostępne są także inne programy tego typu takie jak np.: Anty-plagiat (zob. http://anty-plagiat.softonic.pl). 
serwisu - mają mieć wyłącznie charakter pomocniczy. I tak współczynnik nr 3 wyliczany jest identycznie jak ten pierwszy, ale zaznacza podobieństwo fragmentów zawierających 8 kolejnych wyrazów, które są odnalezione w bazach danych składających się z aktów prawnych. Współczynnik nr 4 tworzony jest $\mathrm{z}$ kolei analogicznie do wskaźnika nr 2 , z tą jednak różnica, iż tak jak w przypadku współczynnika 3 przeszukuje bazy aktów normatywnych. Wreszcie współczynnik nr 5 pokazuje jaki procent analizowanego materiału składa się wyłącznie z fragmentów o długości co najmniej ośmiu słów zaczerpniętych z aktów normatywnych odszukanych w bazach danych zawierających takie dokumenty (Instrukcja, 2014). Ponadto przygotowywany przez serwis komputerowy raport podobieństwa odszukuje, sortuje i prezentuje wykaz dziesięciu najdłuższych fragmentów, podaje elementy zapożyczone, określa stopień zapożyczeń w danym fragmencie oraz ich liczbę z jednego źródła (Instrukcja, 2014). Dla lepszej przejrzystości, posłużono się różnymi barwami, którymi zaznacza się odpowiednie fragmenty. I tak kolorem zielonym podkreśla się frazy pochodzące $\mathrm{z}$ dzieł odnalezionych w internecie, a na niebiesko z baz aktów prawnych. Na szczególną uwagę zasługują wskazówki i sugestie administratora serwisu dotyczące interpretacji raportu podobieństwa. Jak tu podano, wątpliwości u oceniającego powinno budzić: w przypadku wskaźnika nr 1 przekroczenie progu $50 \%$, a dla współczynnika nr 2 przekroczenie poziomu 5\%. Ponadto autorzy serwisu sugerują poddać szczególnej analizie te wszystkie partie badanej pracy, które zostały określone jako „,najdłuższe fragmenty zidentyfikowane jako podobne" (Instrukcja, 2014). Twórcy tego systemu sugerują, że należy przyjrzeć się uważnie tym partiom tekstu zawierającym liczbę wyrazów ponad 200 jednostek. Zgodnie z instrukcją programu, w takich przypadkach, przy użyciu narzędzia ,zaznacz fragment” należy zweryfikować czy są to dozwolone cytaty. Analizie powinny zostać poddane także wszystkie pozostałe zakreślone partie obejmujące fragmenty przekraczające progi określone przez współczynnik podobieństwa nr 2. Trzeba bowiem zweryfikować, czy są to - jak określą twórcy systemu - „krótkie frazy rozrzucone po całym dokumencie (w takiej sytuacji można je uznać za przypadkowe zapożyczenia), czy też długie fragmenty tekstu sąsiadujące ze sobą i rozdzielone tylko krótkimi frazami" (Instrukcja, 2014). Producent oprogramowania zaleca, aby we wszystkich wyżej wskazanych wypadkach wątpliwości podane w raporcie podobieństwa zostały szczegółowo wyjaśnione.

Zanim odniesiemy się do powyższych zaleceń i wskazówek, warto odwołać się do reguł ochrony własności intelektualnej wynikających z obowiązującego prawa autorskiego. Otóż zgodnie z ustawową definicją 
utworu zamieszczoną w art. 1 ust. 1 ustawy o prawie autorskim i prawach pokrewnych (Ustawa, 1994), przedmiotem prawa autorskiego jest każdy przejaw działalności twórczej o indywidualnym charakterze, ustalony w jakiejkolwiek postaci, niezależnie od wartości, przeznaczenia i sposobu wyrażenia. Jak z powyższego wynika, aby uzyskać status utworu, należy spełnić łącznie cztery warunki, a mianowicie po pierwsze, musi być to wynik działalności człowieka (a nie np. maszyny, zwierzęcia czy przyrody), po drugie, przejaw działalności twórczej, co określa się mianem oryginalności, po trzecie o indywidualnym charakterze, a więc odróżniającym się od innych takich samych aktów twórczych i po czwarte, zaistnieć ustalenie, a więc ,uzewnętrznienie" w dowolnej postaci (Barta, Markiewicz, 2011, s. 19). Nie mają natomiast znaczenia dla kwalifikowania do kategorii utworów takie kwestie jak: wartość utworu (co niekiedy w przypadku dzieł naukowych może mieć istotne znaczenie), jego przeznaczenie, sposób wyrażenia utworu (stopień wkładu twórczego, czy jest to pomysł całkowicie samodzielny, czy zainspirowany inną twórczością, stopień wysiłku umysłowego itp.). W przypadku rozstrzygania kryterium indywidualności, pomocna jest koncepcja statystycznej jednorazowości M. Kummera. Zgodnie z nią, aby ustalić czy przesłanka indywidualności została spełniona, odpowiedzieć należy negatywnie na dwa następujące pytania. Po pierwsze, czy dzieło wcześniej istniało oraz po drugie, czy statystycznie prawdopodobne jest stworzenie takiego samego dzieła w przyszłości (Barta, Markiewicz, 2011, s. 24). W kontekście warto zwrócić uwagę, że o ile zatem współczynnik nr 2 generowany przez system antyplagiatowy zapewne takiego testu nie przejdzie, o tyle w przypadku współczynnika $\mathrm{nr} 1$ generowanego przez system antyplagiatowy, kwestia ta nie jest już taka oczywista. Zapewne dlatego producent oprogramowania sugeruje tak wysoki współczynnik na poziomie 50\%. Choć zawsze pojawia się pytanie dlaczego właśnie $50 \%$, a nie $30 \%$ bądź $60 \%$. Co jeszcze warte podkreślenia, w doktrynie zgodnie przyjmuje się, że odrębnym utworem będzie dzieło składające się z cytatów pochodzących z innych dzieł. Zauważa się, że w takim przypadku ów wymagany wkład twórczy polega na dokonaniu odpowiedniego wyboru i doboru cytatów (Traple, 2011, s. 269). Wydaje się, że to stwierdzenie odnośnie dzieł naukowych będzie miało zastosowanie tylko w nielicznych przypadkach, z pewnością nie odnośnie prac dyplomowych, doktorskich, habilitacyjnych, profesorskich. Nie wynika to jednak z wymogów stawianych przez prawo autorskie, bo na tej płaszczyźnie utwory naukowe nie wyróżniają się jakoś szczególnie od innych, lecz ze względu na warunki stawiane takim dysertacjom przez obowiązujące 
przepisy dotyczące nadawania stopni i tytułów naukowych. W ust. 2 art. 1 prawa autorskiego zamieszczono przykładowe wyliczenie przedmiotów prawa autorskiego, w tym - co należy podkreślić - umieszczono jako odrębną kategorię także utwory naukowe. Ustawodawca jednak nie zdefiniował tego pojęcia. Definicje takie odnaleźć można natomiast w doktrynie (Barta, Markiewicz, Matlak, 2013, s. 39-40; Szaciński, 1993, s. 50-53). I tak według R. Ingardena ,istotą takiego utworu jest ustalenie i zamieszczenie wyników poznania naukowego w badanej dziedzinie, a nadto przekazywanie ich w takiej postaci, aby odbiorcy mogli prowadzić dalej, a nawet rozwijać dorobek poszukiwań w zakresie tego tematu" (Ingarden, 1976, s. 143). Z kolei według A. Szewca do tej kategorii należy zaliczać „wszelkie utwory z zawartością naukową tzn. takie, które stanowią rezultat naukowego procesu poznawczego i które równocześnie w swej podstawowej funkcji komunikacyjnej nie są zorientowane »na siebie«, jak utwory artystyczne, lecz na przedstawienie obiektywne istniejącej rzeczywistości” (Szewc, 1997, s. 24). Autor ten wskazuje na dwie konieczne przesłanki, aby zakwalifikować wytwór ludzkiej działalności do kategorii utworów naukowych, a mianowicie ,a) zrealizowane zostają kryteria naukowości w zakresie tematyki i metody uzyskiwania rezultatów, b) odpowiada wymogom nowości i nieoczywistości (oryginalności) ocenianym z punktu widzenia stanu wiedzy środowiska naukowego" (Szewc, 1997, s. 25). Warto przywołać w tym miejscu także pogląd A. Kopffa, który twierdził, że we wszystkich utworach, w tym i naukowych, można wskazać na trzy odrębne warstwy tj. treść, formę wewnętrzną i formę zewnętrzną. Ta pierwsza warstwa, czyli treść obejmuje stan faktyczny, odkrycie naukowe, idee. Skoro tak, to należy przypomnieć, że zgodnie z art. 1 ust. $2^{1}$ prawa autorskiego (ustawa 1994) ochroną objęty może być wyłącznie sposób wyrażenia. Natomiast nie są objęte ochroną odkrycia, idee, procedury, metody i zasady działania oraz koncepcje matematyczne. Zatem to wszystko co składa się na treść w myśl tego ujęcia nie jest objęte w ogóle ochroną prawnoautorską. Natomiast chronione będą forma wewnętrzna i zewnętrzna utworu. Według tej koncepcji forma wewnętrzna wyraża się w doborze argumentów, ich następstwie, gradacji, a w szczególności w kompozycji otworu. Z kolei forma zewnętrzna widoczna będzie w doborze słów, budowie zdań, stylistyce (cyt. za Bieganowska, 1998, s. 22; por. Markiewicz, 1990, s. 22-45; Barta, Markiewicz, Matlak, 2013, s. 39). Według nieco innej koncepcji M. Staszkowa w utworach naukowych należy wyróżniać temat, treść i formę. Ten pierwszy element nie będzie chroniony, natomiast według tego podejścia 
- treść i forma nie mogą być rozdzielane, co nie może jednak oznaczać, iż ochroną prawnoautorską obejmie się odkrycia naukowe (pogląd ten relacjonuje E. Wojnicka, 1990, s. 16-17). Taka ochrona będzie przysługiwać natomiast odpowiedniemu ,autorskiemu”, a więc oryginalnemu i indywidualnemu sposobowi prezentowania tych ustaleń naukowych (Bieganowska, 1998, s. 22). Nieco inny pogląd prezentują J. Barta i R. Markiewicz, którzy twierdza, że konieczne jest odróżnianie przedmiotu poznania i przedmiotu, który został opisany w utworze. Ten ostatni element jest przejawem twórczego działania (Barta, Czajkowska-Dąbrowska, Ćwiąkalski, Markiewicz, Traple, 1995, s. 53-54). Autorzy ci podkreślają, że w tego typu utworach watpliwości może budzić spełnienie cechy indywidualności, a to z tej przyczyny, że stosuje się powszechnie przecież naukowo zweryfikowane metody badawcze, a nadto przedmiot badań jest ogólnodostępny i wspólny. Dodatkowo trzeba dostrzegać różnice wynikające ze specyfiki danej nauki. I tak inaczej wyglądają dzieła naukowe w naukach humanistycznych i przyrodniczych. Abstrahując jednak od tych różnic, podzielić należy pogląd, że przesłanki twórczości, a więc oryginalności (przejawu działaności twórczej) i indywidualności (idywidualnego charakteru) utworów naukowych dostrzegać należy w sposobie dowodzenia, wyjaśniania, weryfikacji oraz doborze argumentacji (Barta, Markiewicz, 2003, s. 23-24; Barta, Markiewicz, 2011, s. 22).

Skoro omawiane usługi określane są jako systemy antyplagiatowe, warto w tym miejscu przybliżyć pojęcie plagiatu (Skrzypczak, 2014, s. 213-226). Tym bardziej, że nie definiuje go ustawa o prawie autorskim i prawach pokrewnych (Sieńczyło-Chlabicz, 2010, s. 133). Wskazać jednak trzeba, że termin ten pojawia się w kilku innych aktach normatywnych. I tak przywołać tu trzeba art. 211 ust. 5 Prawa o szkolnictwie wyższym (Ustawa, 2005). Przypomnieć należy, że przepis ten stanowi, iż „nie stosuje się przedawnienia w odniesieniu do wszczęcia postępowania dyscyplinarnego wobec studenta, któremu zarzuca się popełnienie plagiatu". Z kolei § 11 ust. 1 Rozporządzenia MNiSW w sprawie warunków prowadzenia studiów na określonym kierunku i poziomie kształcenia (Rozporządzenie, 2011) otrzymał następujące brzmienie ,[...] Wewnętrzny system zapewnienia jakości może uwzględniać działania uczelni w zakresie zapobiegania i wykrywania plagiatów". Mimo użycia tego terminu, żaden z wyżej wymienionych aktów normatywnych także nie zawiera definicji legalnej tego pojęcia. Jednak w doktrynie takie definicje można odnaleźć. I tak według M. Szacińskiego są to „cytaty i zapożyczenia z pominięciem podania źródła, bądź jako przywłaszczenie sobie cudzego 
utworu, wydanie go pod własnym nazwiskiem, dosłowne zapożyczenie z cudzych podane jako twórczość własna" (Szaciński, 1981, s. 27). W literaturze przeprowadza się rozmaite typologie tego zjawiska. Podstawowy podział zakłada, iż można wyróżnić plagiat jawny i ukryty. Plagiat jawny polega na nieuprawnionym przejęciu całości lub części cudzego utworu bez własnego wkładu twórczego (Wojnicka, Giesen, 2013, s. 309). Działanie takie może być zakwalifikowane jako plagiat całościowy, gdy sprawca przywłaszcza cały cudzy utwór. Przyznać jednak trzeba, że takie przypadki spotyka się niezmiernie rzadko. Znacznie częściej występują praktyki, które określa się mianem plagiatu częściowego. W takich sytuacjach nieuprawnione przywłaszczenie obejmuje fragment np. rozdział cudzego utworu (Sobczak, 2000, s. 111). Najczęściej wykrywaną odmianą plagiatu jawnego - zgodnie z koncepcją typologii plagiatu autorstwa B. Michalskiego - będzie tzw. plagiat cytatowy, polegający na umieszczeniu we własnej pracy mniejszych fragmentów cudzych utworów, które powinny być wskazane jako cytaty (Michalski, 1998, s. 160). Zatem nawet jeden taki przypadek (np. jedno zdanie) zanotowany w pracy będzie stanowił już plagiat cytatowy. Jak widać w takich przypadkach systemy antyplagiatowe posługujące się określonym progiem np. 5\%, nie uwzględniają tej specyfiki prawa autorskiego. Dla porządku warto odnotować, że B. Michalski do kategorii plagiatu ukrytego zaliczał plagiat redakcyjny, inkorporacyjny, adaptacyjny i współautorski. Plagiat redakcyjny to utwór stworzony w wyniku odpowiednich prac redakcyjnych, a więc poprzez odpowiednią selekcję i zestawienie materiałów innych autorów według założonego klucza (Michalski, 1998, s. 160 i n.; Sobczak, 2000, s. 111). Plagiat inkorporacyjny to - według tej koncepcji - skorzystanie z dosłownych lub tylko nieco zmienionych fragmentów cudzych utworów bez podania źródła i autora. Plagiat adaptacyjny to nieuprawnione dokonanie opracowania cudzego utworu bądź jego fragmentu, np. poprzez tłumaczenie obcojęzycznego tekstu i brak umieszczenia nazwiska autora oryginału. Wreszcie plagiat współautorski miałby polegać na zespoleniu cudzych i własnych fragmentów twórczych (Sieńczyło-Chlabicz, 2010, s. 137). Na uwagę zasługuje pogląd zaprezentowany w wyroku SN z dnia 20 maja 1983 r. iż ,zarzut plagiatu jest prawdziwy nie tylko w przypadku plagiatu jawnego, ale także ukrytego (przeróbka cudzego utworu podana za utwór własny) lub częściowego (wykorzystanie tylko niektórych części, partii utworu cudzego)" (Wyrok SN, 1983). Co warte podkreślenia, o ile systemy antyplagiatowe będą przydatne w wykryciu plagiatu jawnego, o tyle będą bezsilne w przypadku plagiatów ukrytych. W przypadku dzieł naukowych taka praktyka 
może przybrać postać właściwie wszystkich postaci plagiatu ukrytego, a więc redakcyjnego, inkorporacyjnego, adaptacyjnego i współautorskiego.

Jak jednak widać, powyższa typologia nie jest wyrazista, ale co najważniejsze niemająca właściwie żadnego uzasadnienia normatywnego. Pojawiają się wręcz głosy, że kategoria ta jest wręcz wysoce dezorientująca, z uwagi na brak ustawowych wytycznych definicyjnych, rozmaite koncepcje i typologie obecne w doktrynie, konieczność sprecyzowania w każdym przypadku znaczenia w jakim ten termin jest używany, czy działanie takie ma znamiona deliktu prawa autorskiego w zakresie autorskich praw osobistych, czy też majątkowych (Błeszyński, 2014, s. 119). Co więcej obowiązujące regulacje prawne w każdym przypadku, który określany jest potocznie jako plagiat, posługują się innym opisem zabronionych działań. I tak zgodnie z art. 126 pkt 3 i art. 139 ust. 1 Prawa o szkolnictwie wyższym (Ustawa, 2005) zwolnienie dyscyplinarne lub odpowiedzialność dyscyplinarna grozi pracownikowi naukowemu w przypadku: dopuszczenia się czynu określonego w art. 115 prawa autorskiego (Ustawa, 1994); przywłaszczenia sobie autorstwa albo wprowadzenia w błąd co do autorstwa całości lub części cudzego utworu albo artystycznego wykonania, rozpowszechnienia bez podania nazwiska lub pseudonimu twórcy cudzego utworu w wersji oryginalnej albo w postaci opracowania; rozpowszechnienia, bez podania nazwiska lub pseudonimu twórcy, cudzego artystycznego wykonania albo publicznego zniekształcenia takiego utworu, artystycznego wykonania, fonogramu, wideogramu lub nadania, a także innego sposobu naruszenia cudzych praw autorskich lub praw pokrewnych. Z kolei w myśl postanowień art. 167a Prawa o szkolnictwie wyższym (Ustawa, 2005) pracy dyplomowej stawia się warunek, aby była ona „samodzielnym opracowaniem określonego zagadnienia naukowego prezentującym ogólną wiedzę i umiejętności studenta związane z danym kierunkiem studiów, poziomem i profilem kształcenia oraz umiejętności samodzielnego analizowania i wnioskowania" (Ustawa, 2005). Analizując powyższy przepis, warto rozważyć w kontekście prezentowanej tu problematyki, jak należy rozumieć termin „samodzielne opracowanie określonego zagadnienia naukowego". Oczywiście błędnym musi być stwierdzenie, że praca taka nie może zawierać odwołań do innych prac naukowych poprzez użycie cytatów z innych utworów i składać się wyłącznie z własnej autorskiej treści. Wydaje się wręcz, że praca pozbawiona odniesień do literatury przedmiotu, nie spełnia wymogów o których mowa w tym przepisie. Trudno bowiem uznać, że taki przypadek spełniałby wymóg ,prezentowania ogólnej wiedzy i umiejętności studenta związane 
z danym kierunkiem studiów, poziomem i profilem kształcenia" (art. 167a ustawy 2005). W kontekście wskaźników nr 1 i 2 warto postawić pytanie, jaki jest dopuszczalny poziom cytatów. Czy jeżeli praca składałaby się z samych cytatów byłaby samodzielnym opracowaniem, o którym mowa w tym przepisie? Jak wyżej wskazano byłoby to zgodne z prawem autorskim. Zasady warsztatu naukowego oraz wskazania określone w art. 167a ustawy wymagają jednak, aby obok przytoczenia poglądów innych badaczy zaprezentować własny pogląd w tym zakresie, a przynajmniej ustosunkować się do przedstawianej dyskusji naukowej. W ten tylko sposób - jak się wydaje - student może zaprezentować „umiejętności samodzielnego analizowania i wnioskowania" (art. 167a ustawy 2005). Nie można jednak w sposób niejako zryczałtowany, zautomatyzowany ustalić jaki procent powinna stanowić element samodzielnego analizowania i wnioskowania. Z kolei odnośnie rozpraw doktorskich obowiązujące regulacje wymagają, aby dysertacja taka stanowiła „oryginalne rozwiązanie problemu naukowego lub oryginalne dokonanie artystyczne" oraz wykazywała ogólną wiedzę teoretyczną kandydata w danej dyscyplinie naukowej lub artystycznej oraz umiejętność samodzielnego prowadzenia pracy naukowej lub artystycznej. Wydaje się, że wszystkie powyższe uwagi odnośnie prac dyplomowych będą w tym przypadku także aktualne i znajdą zastosowanie. Trzeba tu dodać, że zgodnie z art. 29a. ust. 1 tego aktu normatywnego rada właściwej jednostki organizacyjnej lub Centralna Komisja, stwierdza nieważność postępowania w sprawie nadania tytułu lub stopnia, co skutkuje jego utrata, ,jeżeli w pracy stanowiącej podstawę nadania tytułu lub stopnia osoba ubiegająca się o tytuł lub stopień przypisała sobie autorstwo istotnego fragmentu lub innych elementów cudzego utworu lub ustalenia naukowego" (Ustawa, 2003). Jak widać, w żadnym z tych aktów normatywnych choć nie pojawia się pojęcie plagiatu, piętnuje się zachowania przywłaszczenia autorstwa, wskazując poprzez stosowny opis znamiona czynów zabronionych. Tu oczywiście pojawia się z kolei wątpliwość co należy rozumieć pod pojęciem, ,istotnego fragmentu” cudzego utworu. Wydaje się, że w każdym przypadku należy stosować indywidualną ocenę, a nie kierować się jakimiś ustalonymi wskaźnikami, np. 5\%. Niekiedy może to być nawet bardzo krótki fragment, który jest np. istotnym elementem pracy, a w innych może „obronić się” mniej znaczący fragment, ale nieco dłuższy. W każdym z powyższych przypadków dojdzie do naruszenia prawa autorskiego, ale nie zawsze musi to skutkować konsekwencjami określonymi w art. 29a ust. 1 ustawy. Trzeba też pamiętać, że ocena prac dyplomowych i doktorskich jest rozbudowana (od nie- 
dostatecznej do celującej) i jednym z czynników wpływających na jej wysokość powinny być wyżej zaprezentowane przesłanki.

Dodatkowo w tym miejscu warto wyjaśnić, że działaniem całkowicie zgodnym z prawem może być korzystanie z cudzego opracowania, materiału, dokumentu. Chodzi po pierwsze o te kategorie, które zostały ustawowo wyłączone z katalogu przedmiotów prawa autorskiego. Do tej grupy - zgodnie z art. 4 prawa autorskiego należy zaliczyć akty normatywne lub ich urzędowe projekty, urzędowe dokumenty, materiały, znaki i symbole, opublikowane opisy patentowe lub ochronne, proste informacje prasowe. Stąd też całkowicie zgodnie z prawem można przytaczać we własnych pracach naukowych powyższe kategorie, np. orzeczenia sądów i ich uzasadnienia, decyzje i inne dokumenty administracyjne, urzędowe projekty aktów normatywnych. Ma to szczególne znaczenie - co oczywiste - w przypadkach prac prawniczych, a także - z pewnością już w mniejszym zakresie - przygotowywanych na wydziałach nauk politycznych i dziennikarstwa. Dlatego też wydaje się, że wskaźniki nr 3, 4 oraz 5, o których mowa była powyżej, w zasadzie nie powinny mieć większego znaczenia. Trzeba tu wszakże zaznaczyć, że sam producent tego progra$\mathrm{mu}$, zaleca jedynie zastosowanie pomocnicze tych danych.

Po drugie i istotniejsze, prawo autorskie zezwala na korzystanie z cudzych utworów w ramach tzw. dozwolonego użytku z chronionych utworów (prywatnego lub publicznego). $\mathrm{Z}$ punktu widzenia problematyki opisywanej w niniejszym opracowaniu na uwagę zasługuje szczególnie tzw. prawo cytatu. Otóż zgodnie z art. 29 ust. 1 prawa autorskiego dopuszczalne jest zamieszczanie urywków cudzych utworów lub drobnych utworów w całości. W przypadku prac naukowych zazwyczaj będziemy mieli do czynienia $\mathrm{z}$ tym pierwszym przypadkiem, a więc umieszczaniem fragmentów cudzych utworów. Warunkiem legalizującym takie działanie jest po pierwsze, aby tak stworzony utwór, sam w sobie stanowił samoistną całość, spełniał warunki stawiane w art. 1 prawa autorskiego (Preussner-Zamorska, Marcinkowska, 2013, s. 564-565). Po drugie, jest to dopuszczalne tylko „w zakresie uzasadnionym wyjaśnianiem, analizą krytyczną, nauczaniem lub prawami gatunku twórczości” (Ustawa, 1994). Jeżeli chodzi o wspomniane wyżej prawa gatunku twórczości, to chodzi tu zwykle o takie przypadki jak: parodia, satyra, karykatura. W przypadku dzieł naukowych nie będzie to zatem miało istotnego zastosowania. $\mathrm{Na}$ marginesie jedynie warto zaznaczyć, że niekiedy na wstępie pracy, bądź kolejnych rozdziałów umieszcza się motto. Taka praktyka w tym kontekście będzie w pełni dozwolona (Traple, 2011, s. 270). Z pewnością zasadni- 
cze znaczenie w pracach naukowych będzie miał cel cytatu określany jako wyjaśnianie, analiza krytyczna czy też nauczanie. Przejmowany fragment z cudzego dzieła ma zatem służyć lepszemu wyrażeniu własnych myśli. Stąd też w pełni na aprobatę zasługuje pogląd, że „wskazówką, iż mamy do czynienia z niedozwolonym wykorzystaniem cudzego dzieła, jest brak wewnętrznego, niezbędnego związku między wywodami autora posługującego się cytatem a treścią cytatu" (Traple, 2011, s. 269). Na tym jednak nie koniec warunków, które należy spełnić. Otóż zgodnie z art. 34 prawa autorskiego wymaga się, aby w takim przypadku wskazać twórcę i źródło. Pod tym pojęciem rozumie się właściwe oznaczenia autora, względnie wydawcy w przypadku słownika lub encyklopedii (Traple, 2011, s. 288). Należy nadto podkreślić, że ustawa nie określa w jakiś sztywny sposób rozmiaru przejmowanego cudzego dzieła np. poprzez podanie rozmiaru. Przyjmuje się jednak, że taki zakres będzie wynikać z celu dla jakiego został dokonany. I tak w przypadku analizy krytycznej dopuszczalny rozmiar cytatu będzie wynikać z okoliczności, które powodują, że tak przeprowadzana krytyka będzie dla odbiorcy czytelna i zrozumiała (Barta i in., 1995, s. 200-201). Z kolei wyjaśnianie i nauczanie wiąże się niekiedy z potrzebą sięgnięcia po większy fragment, aby właściwie argumentować własne wywody. Dlatego należy w pełni podzielić pogląd, że „nie jest zatem możliwe posłużenie się generalnymi kryteriami ilościowymi, wyrażającymi dopuszczalny procent cytatu w stosunku do reszty dzieła, z którego pochodzi, i w odniesieniu do dzieła posługującego się cytatem. Kryterium decydującym o dozwolonym rozmiarze jest wyłącznie cel cytowania, natomiast wielkość przejmowanego fragmentu w stosunku do każdego z utworów może stanowić jedynie pomocniczą wskazówkę" (Traple, 2011, s. 271). Ponadto wydaje się, że nie może mieć znaczenia dla ustalenia czy zakres i sposób cytowania jest właściwy, ustalenie $\mathrm{w}$ jakiej ilości kopii tekst zawierający przejmowany fragment jest udostępniony. Inne stanowisko, krytykowane powszechnie, zajął SN w wyroku z 27 stycznia 1981 r. ICR 390/80, który stwierdził, iż przejęcie 3 rysunków bez podania autora i źródła w materiale mającym charakter nieformalnego doniesienia naukowego i w nakładzie 200 egz. dystrybuowanych wyłącznie w gronie uczestników konferencji naukowej nie stanowi naruszenia prawa autorskiego (Traple, 2011, s. 269).

Kolejną istotną kwestią jest właściwe oznaczenie cytatu. Wprawdzie w wyroku SN dnia 29.12.1971 r. (Wyrok SN, 1971) sformułowano teze, że ,zakres przedrukowania fragmentów cudzych prac autorskich i sposób wskazywania źródeł jest normowany przez przepisy prawa autorskiego, 
a nie przez stosowane w praktyce zwyczaje", to jednak trudno ten pogląd w pełni podzielić nawet przyjmując, że stanowisko to zostało sformułowane na gruncie ustawy o prawie autorskim z 1952 r. (Ustawa, 1952) i to zarówno przez pryzmat przepisów już uchylonych, jak i obowiązujących. Wręcz przeciwny pogląd prezentowali J. Błeszyński (Błeszyński, 1985, s. 119-120) i E. Traple (Barta i in., 1995, s. 214). Wyżej wymienieni autorzy twierdzą, że możliwe, a nawet konieczne jest odwołanie się w tym zakresie do panujących dobrych zwyczajów i praktyki wydawniczej (Wiśniewski, 1973, s. 781-787; Preussner-Zamorska, Marcinkowska, 2013, s. 567), a w każdym przypadku konieczne będzie - jak już wyżej sygnalizowano - podanie źródła i autora oraz wyraźne oznaczenie przejętego fragmentu cudzego dzieła (Błeszyński, 1985, s. 120). Natomiast w pełni na aprobatę zasługuje druga z tez przytoczonego powyżej stanowiska SN. Z pewnością zatem nie można uznać za wystarczającą praktykę polegającą na wskazaniu w bibliografii dzieła naukowego utworu, z którego zaczerpnięto cytat we wcześniejszych partiach tekstu. W praktyce funkcjonuje kilka sposobów oznaczania cudzego fragmentu tekstu we własnym tekście. Zwykle taki materiał umieszcza się w cudzysłowie bądź oznacza kursywą. Wydaje się jednak, że w wyjątkowych przypadkach dopuszczalna będzie praktyka polegająca na rezygnacji w dziełach naukowych z powyższych zasad, np. poprzez zastosowanie innych technik graficznych lub edytorskich. Tak będzie chociażby w przypadku umieszczenia motta w miejscu wyróżnionym. Tym niemniej nie może to oznaczać zaniechania spełnienia warunków wskazanych w art. 34 w zw. z art. 29 ust. 1 prawa autorskiego. Ponadto praktyka taka - zgodnie z art. 35 prawa autorskiego - nie może godzić w interesy twórcy. W przywoływanym już wcześniej orzeczeniu z 29.12.1971 r. podkreślono, że „Wymaganiu wyraźnego wymienia źródła, z którego pochodzi fragment cudzego dzieła [...], nie czyni zadość wymienienie tego dzieła w zestawieniu literatury bez jakiegokolwiek wyjaśnienia ani zasady, ani stopnia wykorzystania tego dzieła, a w szczególności bez wskazania, że dokonano z niego przedruku określonej treści” (Wyrok SN, 1971). Zatem przypadek polegający na zebraniu prac autorów i ich dzieł w końcowej części materiału byłby dopuszczalny z punktu widzenia prawa autorskiego, ale pod warunkiem, że w pracy nie wykorzystano cytatów. Inną sprawą będzie ocena takiej praktyki z punktu widzenia warsztatu naukowego.

Regułą powinno być, aby cytowany fragment utworu przytoczyć bez jakichkolwiek zmian. Dopuszcza się jedynie odstępstwo w przypadku tłumaczenia (Traple, 2011, s. 268). Dyskusyjne jest czy np. poprawki 
błędów ortograficznych, gramatycznych lub stylistycznych są dopuszczalne. Wydaje się, że taka ingerencja, choć często w imię dobra autora, może naruszać jego autorskie prawa osobiste.

Z kolei warte podkreślenia jest, że taka praktyka, a nawet zwyczaj wytworzyły się odnośnie wskazywania autora i źródła. Trzeba też zaznaczyć, że funkcjonuje co najmniej kilka systemów tworzenia przypisów. W tzw. klasycznym lub tradycyjnym na końcu cytatu umieszcza się odnośnik liczbowy, który odsyła do dołu strony lub końca rozdziału i tam podaje się inicjały imienia i nazwiska autora lub autorów. W przypadku odwołania do dzieła współautorskiego, ryzykownym zabiegiem będzie podanie tylko pierwszego nazwiska z dodatkowym oznaczeniem ,,i inni”. O ile dopuszczalny byłby taki zabieg w przypisie, w bibliografii należałoby uhonorować wszystkich autorów dzieła współautorskiego. W przeciwnym razie można doszukiwać się naruszenia autorskich praw osobistych tych „,innych" autorów. Inaczej ocenić należy praktykę prac zbiorowych wydanych pod redakcja naukową jednego $\mathrm{z}$ autorów. W takim przypadku wystarczy podanie danych redaktora tomu. Ale wówczas odwołując się do fragmentu (np. artykułu) przygotowanego przez danego autora, należy także podać jego imię i nazwisko. Jeżeli chodzi o podanie źródła to wskazuje się tytuł pracy, miasto siedziby wydawcy wraz z datą wydania, ewentualnie niekiedy obok lub zamiast podaje się nazwę wydawcy oraz stronę, z którego pochodzi cytat. W pełni dopuszczalną praktyką jest, aby w sytuacji wielokrotnego przywołania danego dzieła posłużyć się odpowiednim skrótami w języku polskim lub łacińskim. I tak jeżeli chodzi o powtórzenie nazwiska autora stosuje się takie oznaczenia jak „tenże” - ,idem”, „taże” - „eadem”, a powtarzając tytuł utworu używa się oznaczeń skrótowych takich jak ,op. cit.”, „dzieło cytowane”, „,dz. cyt.”, „ibidem”, „tamże" itd. Wszystkie powyższe uwagi znajdą zastosowanie także odnośnie źródeł internetowych, z tym, że należy podać wówczas dokładny adres strony, na której umieszczony jest tekst i datę wejścia na tę stronę www. Z kolei w systemie tzw. harwardzkim wskazuje się w samym tekście na zakończenie cytatu nazwisko lub nazwiska autorów (ewentualnie w przypadku wielu autorów oznaczenie ,i inni”) i daty wydania pracy wraz z numerem strony z której pochodzi zaczerpnięty fragment. Na końcu całej pracy zamieszcza się bibliografię z oznaczeniem roku wydania przy nazwisku autora. Niekiedy również praktykuje się wersję uproszczoną polegającą na podaniu w tekście tylko kolejnej cyfry w nawiasie kwadratowym wraz z numerem strony. Pełne dane bibliograficzne umieszcza się w tym przypadku także na końcu tekstu z właściwym oznaczeniem cyframi. 
Zgodzić należy się także z tezą zaprezentowaną w przywoływanym na wstępie raporcie NIK, iż ,warunkiem koniecznym poszanowania praw autorskich w pracach dyplomowych jest zapewnienie studentom odpowiedniego poziomu wiedzy w tym zakresie". Jak podkreślono w tym dokumencie ,jedną z przyczyn nieprawidłowości stwierdzonych w wyniku kontroli często była niepełna wiedza o zasadach poszanowania cudzej własności intelektualnej, cytowania literatury i materiałów źródłowych" (Raport, 2014, s. 7). Warto podkreślić, że zgodnie z rozporządzeniem Ministra Nauki i Szkolnictwa Wyższego z 2.11.2011 r. w sprawie Krajowych Ram Kwalifikacji dla Szkolnictwa Wyższego (Rozporządzenie MNiSW, 2011) wymaga się, aby absolwent miał wiedzę i umiejętności w zakresie ochrony własności intelektualnej. Wydaje się, że to jednak nie wystarczy. Stąd konieczne jest podjęcie innych działań (np. umieszczania stosowanych oświadczeń o samodzielności pracy jako element profilaktyczny i edukacyjny). Komputerowe programy antyplagiatowe o których mowa w opracowaniu są instrumentem przydatnym, ale nie idealnym. Z pewnością żaden z promotorów, nawet najlepszy i najbardziej zaangażowany, nie jest w stanie śledzić dziś wszystkich doniesień naukowych, zwłaszcza tych dostępnych $w$ internecie. Ponadto $\mathrm{z}$ reguły osoby sprawujące pieczę nad przygotowywaniem prac dyplomowych przez studentów nie maja dostępu do prac dyplomowych, które powstały na innych uczelniach, a nawet na rodzimej placówce $u$ innych pracowników naukowych. A przecież wiele plagiatów pochodzi z takich źródeł. I w tych przypadkach rozwiązania te są wręcz bezcenne. Wśród wad należy jednak wymienić - mimo wszystko - ciaggle wąską bazę materiałów porównawczych. Wydaje się jednak, że wraz z rozwojem tych systemów (z biegiem lat) oraz większymi środkami na zakup pełnych wersji takiego oprogramowania, ten mankament będzie coraz mniej znaczący. Jak można odnaleźć w internecie, istnieją łatwe sposoby oszukania systemu. Mając jednak na uwadze, że niniejsze opracowanie być może będzie materiałem edukacyjnym, należy spuścić zasłonę milczenia na takie praktyki, a tym bardziej nie zamieszczać tu swoistego instruktażu dla takich praktyk. Co jednak istotniejsze, systemy te nie uwzględniają do końca specyfiki praw autorskich. Z jednej strony nie są przydatne w wykryciu plagiatu ukrytego. Ponadto zaznaczają partie tekstu, wykazujące podobieństwo czy wręcz identyczność. Niekiedy jednak dotyczy to materiałów, które bądź nie są chronione prawem autorskim, bądź przepisy o dozwolonym użytku zezwalają, pod pewnymi warunkami o których mowa była powyżej, na pełnoprawne z nich korzystanie. Jak się wydaje, tego rodzaju rozwiązania informatyczne 
nie uwzględniają specyfiki określonych rodzajów nauki, np. nauk technicznych, a z drugiej prac naukowych w obrębie nauk prawnych i pokrewnych, w których konieczne bardzo często staje się przytoczenie dosłownie zapisów zaczerpniętych z aktów normatywnych bądź wyroków sądów i innych dokumentów urzędowych. Ponadto posługują się określonymi wskaźnikami, które w żaden sposób nie przystają do obowiązujących regulacji prawnych w tym zakresie. Chociażby zezwalają na pewien procent zapożyczeń np. 5\% (uprawnionych i nieuprawnionych), choć każde nieuprawnione zapożyczenie jest naruszeniem prawa autorskiego. Konkludując jednak należy stwierdzić, że jest to rozwiązanie użyteczne, bowiem pomagające wykryć nieetyczne praktyki. Jednak koniecznie wymaga zweryfikowania przez promotora, którego - co powinno zabrzmieć w sposób niezwykle optymistyczny dla kadry akademickiej - nie zastapi żaden system komputerowy. Nic nie zastappi także hołdowania podstawowym zasadom etyki, które powinny być przestrzegane, zwłaszcza w środowisku akademickim.

\section{Bibliografia}

Barta J. (1977), Plagiat muzyczny, „Zeszyty Naukowe UJ. Prace z Wynalazczości i Ochrony Własności Intelektualnej”, z. 17.

Barta J. (red.) (2003), System Prawa Prywatnego. Prawo autorskie, t. 13, wyd. 1, Warszawa.

Barta J. (red.) (2003), System Prawa Prywatnego. Prawo autorskie, t. 13, Warszawa.

Barta J. i inni (1995), Komentarz do ustawy o prawie autorskiem i prawach pokrewnych, Warszawa.

Barta J., Markiewicz R. (2003), Specyficzne problemy dotyczqce niektórych kategorii utworów. Utwory naukowe, w: System Prawa Prywatnego. Prawo autorskie, red. J. Barta, t. 13, wyd. 1, Warszawa.

Barta J., Markiewicz R., Matlak A. (2013), Specyficzne problemy dotyczqce niektórych kategorii utworów, w: System Prawa Prywatnego. Prawo autorskie, red. J. Barta, t. 13, wyd. 3, Warszawa.

Bieganowska M. (1998), Ochrona autorskoprawna pracowniczych utworów naukowych, „Przegląd Ustawodawstwa Gospodarczego”, nr 11.

Błeszyński J. (1985), Prawo autorskie, Warszawa.

Błeszyński J. (2014), Watpliwości dotyczqce plagiatu, w: Dziennikarz, utwór, prasa. Ksiegga jubileuszowa z okazji 50-lecia pracy naukowej prof. dr hab. Bogdana Michalskiego, red. T. Kononiuk, Warszawa. 
Informacja NIK (2014) o wynikach kontroli: Ochrona praw autorskich w pracach dyplomowych w szkołach wyższych, LKI-401-12-00/2013; nr eweid. 66/2014.P131149/LKI, https:/www.nik.gov.pl/plik/id,7598,vp,9530.pdf, 10.02.2015.

Ingarden R. (1976), O poznaniu dzieła literackiego, przekład z j. niemieckiego D. Gierulanka, Warszawa.

Instrukcja (2014) interpretacji raportu podobieństwa serwisu plagiat.pl, zob. https://www.plagiat.pl/cms_pdf/Plagiat_pl_Instrukcja_intepretacji_Raportu_Podobienstwa_nowa.pdf, 10.12.2014.

Kopff A. (1961), Dzieło sztuk plastycznych i jego twórca w świetle przepisów prawa autorskiego, Kraków.

Kopff A. (1973), Ttumaczenie i jego twórca w polskim prawie autorskim, Warszawa.

Markiewicz R. (1990), Ochrona prac naukowych, „Zeszyty Naukowe UJ. Prace z Wynalazczości i Ochrony Własności Intelektualnej”, Warszawa-Kraków, z. 55.

Michalski B. (1998), Podstawowe problemy prawa prasowego, Warszawa.

Preussner-Zamorska J., Marcinkowska J. (2013), Prawo cytatu, w: System Prawa Prywatnego. Prawo autorskie, red. J. Barta, t. 13, Warszawa.

Rozporządzenie MNiSW (2011) z dnia 5 października 2011 r. w sprawie warunków prowadzenia studiów na określonym kierunku i poziomie kształcenia, t.j. Dz. U. 2014, poz. 131.

Rozporządzeniem MNiSW (2011) z 2 listopada 2011 r. w sprawie Krajowych Ram Kwalifikacji dla Szkolnictwa Wyższego, Dz. U. Nr 253, poz. 1520.

Sieńczyło-Chlabicz J. (2010), Odpowiedzialność nauczycieli akademickich, doktorantów i studentów z tytulu popetnienia plagiatu, „Transformacje Prawa Prywatnego", nr 1.

Skrzypczak J. (2014), Plagiat dzieł naukowych, ,Środkowoeuropejskie Studia Polityczne", nr 4.

Sobczak J. (2000), Prawo autorskie i prawa pokrewne, Warszawa-Poznań.

Szaciński M. (1981), Naruszenie autorskich dóbr osobistych w postaci plagiatu, niedozwolonych zapożyczeń oraz znieksztatceń utworu, „Palestra”, nr 6.

Szaciński M. (1993), Wkład twórczy jako przesłanka dzieła chronionego prawem autorskim, „PiP”, z. 2, s. 50-53.

Szewc A. (1997), Dzieła naukowe i ich status w prawie autorskim, „Państwo i Prawo”, nr 10.

Traple E. (2011), Komentarz do art. 29 prawa autorskiego, w: Prawo autorskie i prawa pokrewne, red. J. Barta, R. Markiewicz, Warszawa.

Ustawa (1952) z dnia 10 lipca 1952 o prawie autorskim, Dz. U. Nr 34, poz. 234 z późn. $\mathrm{zm}$.

Ustawa (1994) z dnia 4 lutego 1994 r. o prawie autorskim i prawach pokrewnych, tj. Dz. U. 2006, Nr 90, poz. 631 z późń. zm. 
Ustawa (2003) z dnia 14 marca 2003 r. o stopniach naukowych i tytule naukowym oraz o stopniach i tytule w zakresie sztuki, t.j. Dz. U. 2014, poz. 1852.

Ustawa (2005) z dnia 27 lipca 2005 r. Prawo o szkolnictwie wyższym, t.j. Dz. U. 2012, poz. $572 \mathrm{z}$ późn. zm.

Wiśniewski A. (1973), Glosa, „Nowe Prawo”, nr 10.

Wojnicka E. (1990), Autorskie prawa zależne, Łódź.

Wojnicka E. (2003), Plagiat jako wynik przywłaszczenia autorstwa, w: System Prawa Prywatnego. Prawo autorskie, red. J. Barta, t. 13, wyd. 1, Warszawa.

Wojnicka E., Giesen B. (2013), Plagiat jako wynik przywłaszczenia utworu, w: System Prawa Prywatnego. Prawo autorskie, red. J. Barta, t. 13, Warszawa.

Wyrok SN (1971) z dnia 29.12.1971 r., sygn. I CR 191/71 - opublik. w OSNCP 1972, nr 7-8, poz. 133 .

Wyrok SN (1981) z dnia 27 stycznia 1981 r., sygn. akt ICR 390/80.

Wyrok SN (1983) z dnia 20 maja 1983 r., sygn. akt I CR 92/83.

\section{Electronic anti-plagiarism systems as a tool to detect the instances of plagiarism in papers by students and academics}

\section{Summary}

The mass character of academic education, coupled with easy access to the enormous number of sources and studies available on the Internet has resulted in an epidemic of copyright infringement. As of October 1, 2014, higher education institutions in Poland have been required to check students' final dissertations before the final exam with anti-plagiarism software compatible with the national repository of final dissertations. The paper undertakes to clarify the issues of how these IT systems operate and what their importance is as concerns the legal consequences of inadmissible borrowings detected. The issue of the right to quote in Polish copyright law is discussed. Anti-plagiarism software provides a useful, albeit imperfect instrument. It is obvious that no academic advisor or reviewer is able to detect all the borrowings from other works which these systems are able to do. Their shortcomings, however, include the as yet limited database of materials for comparison. The system can also be easily tricked. More important, however, is the fact that these systems are not able to fully account for the specific nature and the essence of copyright protection. They can provide a useful solution, capable of detecting unethical practice, but the outcomes have to be verified by an academic advisor.

Key words: electronic anti-plagiarism systems, plagiarism, copyright infringement, the right to quote 